\title{
Optimization Opportunity for Mine Ventilation and Cooling Plant System at Maddahapara Granite Mine, Dinajpur, Bangladesh
}

\author{
Mohammad Tofayal Ahmed \\ Department of Petroleum and Mining Engineering \\ Jashore University of Science and Technology \\ Jashore-7408,Bangladesh
}

\author{
Amirul Islam \\ Department of Petroleum and Mining Engineering \\ Jashore University of Science and Technology \\ Jashore-7408,Bangladesh \\ Mohammad Forrukh Hossain Khan \\ Department of Petroleum and Mining Engineering \\ Jashore University of Science and Technology \\ Jashore-7408,Bangladesh
}

\author{
Sudipta Kumar Paul \\ Department of Petroleum and Mining Engineering \\ Jashore University of Science and Technology \\ Jashore-7408,Bangladesh \\ Md. Mehedi Hasan \\ Department of Petroleum and Mining Engineering \\ Jashore University of Science and Technology \\ Jashore-7408,Bangladesh
}

\begin{abstract}
Mine ventilation optimization and air flow management are two obligatory features of mine ventilation system. However, blasting creates lots of poisonous and harmful gases during mining operation. Additionally, mine worker faces obstacle due to the presence of fume and poisonous gas. This research work founds that Maddhapara ventilation system losses $20 \%$ of air on various circumstances. This involves the prevention of unwanted circumstance to deliver a sustainable working environment and provide a scientifically proven scheme to prevent mine hazards. The outcome of this research optimizes the ventilation system in Maddahapara Granite Mine which increases air flow rate by installing an air-cooling plant. Maddahapara mine ventilation system should be optimized and controlled by using mine ventilation doors and maintenance of ventilation equipment.
\end{abstract}

Keywords-Optimization, ventilation improvement, poisonous gas, controlling air flow, Temperature controlling

\section{INTRODUCTION}

Maddahapara Granite Mine (MGM) is the unaccompanied one underground jointly jump handle in Bangladesh under the Petrobangla and the Ministry of Power, Energy and Mineral Resources of Bangladesh [1]. MGM is controlling in Maddahapara, Dinajpur sector, northwest Bangladesh, with an outlook of virtually $1.44 \mathrm{~km}^{2}$, mid latitude $25^{\circ} 23^{\prime} 22^{\prime \prime} \mathrm{N}$ and $25^{\circ} 34^{\prime} 43^{\prime \prime} \mathrm{N}$ and longitude $89^{\circ} 03^{\prime} 34^{\prime \prime} \mathrm{E}$ and $89^{\circ} 05^{\prime} 04^{\prime \prime} \mathrm{E}$. In 1974, Geological Survey of Bangladesh (GSB) ran an exploration skim in Maddahapara [2]. In the Maddahapara trend, basement rock is encountered at a depth of $130 \mathrm{~m} \mathrm{[3].}$ An estimated ace in the hole of 174 million tons of jointly rock in MGM consisting of granodiorite, diorite, quartz-diorite and gneiss of the Pre-Cambrian latter part of animate life has been discovered. Mining is a major economic reaction in many economically developing country [4,5]. The mining rule of thumb applied in MGM is room and pillar/ sub-level stopping methods. There are 5 stopes under concept of which two are in the south and three are in the north. The term, height, width and length of each stope are $230 \mathrm{~m}, 60 \mathrm{~m}$ and $20 \mathrm{~m}$, respectively. The invent hole drilling is secondhand in MGM and fan kneejerk reaction is secondhand for blasting operation. Ammonium Nitrate Fuel Oil (ANFO) and power gel are secondhand for blasting purpose. The work of genius of granite is $\sim 1.65$ million tons/yr. Mine operations, whether smaller pervasive, are inherently raucous to the environment [2,6]. The environmental deterioration caused by mining occurs especially as a show once and for all of incongruous and wasteful engrossed practices and rehabilitation measures. Mining has an abode of hack stages or activities, each of which has potentially-adverse impacts on the intuitive environment, crowd and cultural heritage, the brute force and conservation of employ workers, and communities based in complete proximity to operations $[7,8,12]$. The circumstance of this Granite in the rough is to engage out the environmental impacts caused by the fraud of strictly rock in MGM and its accessible remedies and minimization to derive MGM a sustainable mine apprehension. Bangladesh has become a rapid rising country which is facing the problems of both groundwater superiority and extent. Increasing urbanization, population of explosion and exhaustive are the problem contributing factors on agriculture sectors. The Sagardari union, the main studied area, is required to use $50 \%$ of its water prerequisite from groundwater resources. The unlined drains which is opened and the removal of pollution in different locations in the recharge extents act as pollution source of groundwater [5].

\section{VENTILATION SYSTEM AT MADDAHAPARA}

Exhausting ventilation system is used in the Maddahapara mine ventilation System. Different elements of exhausting ventilation system are showed in figure 2,3. 

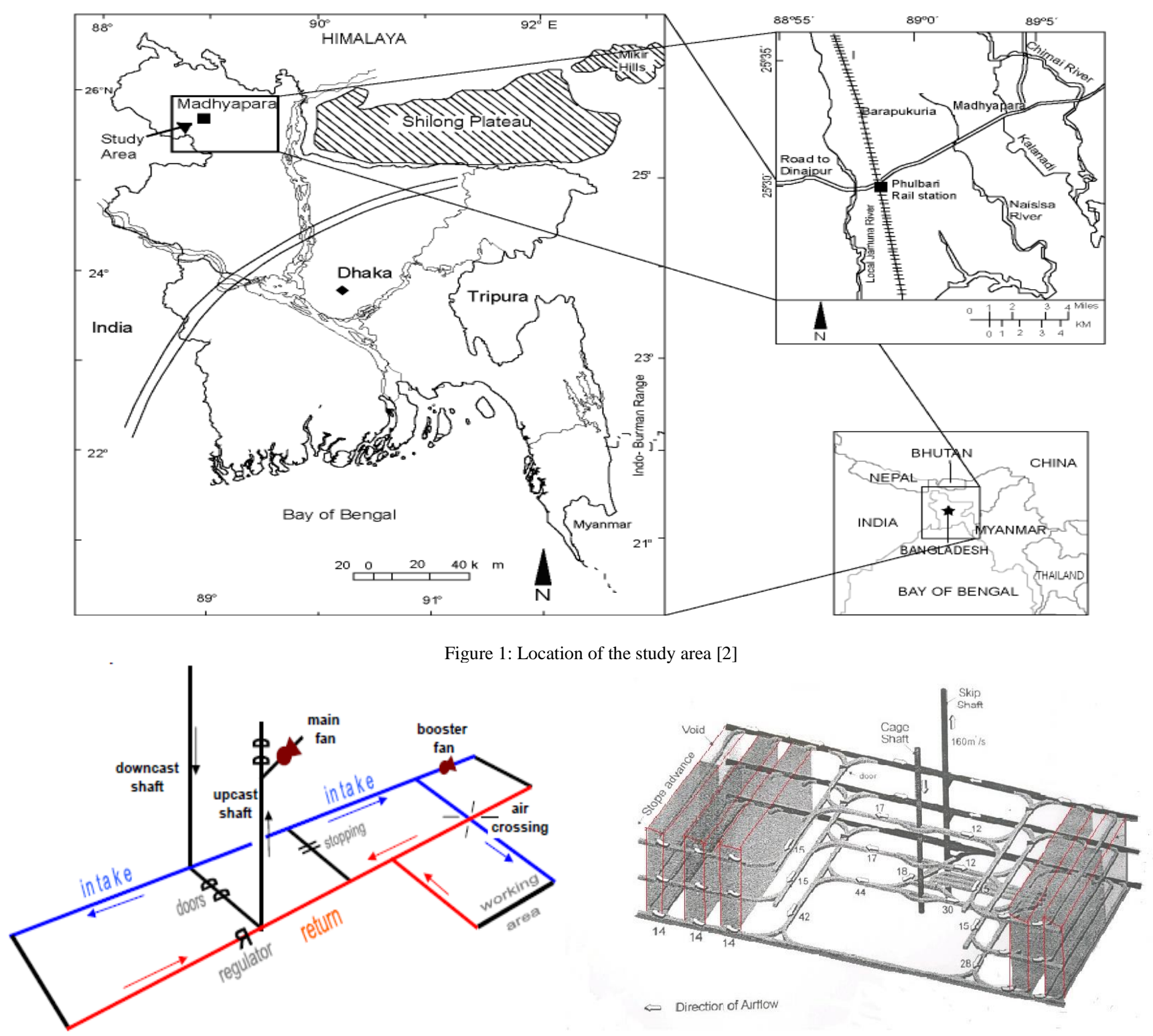

Figure 2: Exhausting ventilation system underground mine [6] Figure 3: Maddhapara ventilation lay-out and air flow direction

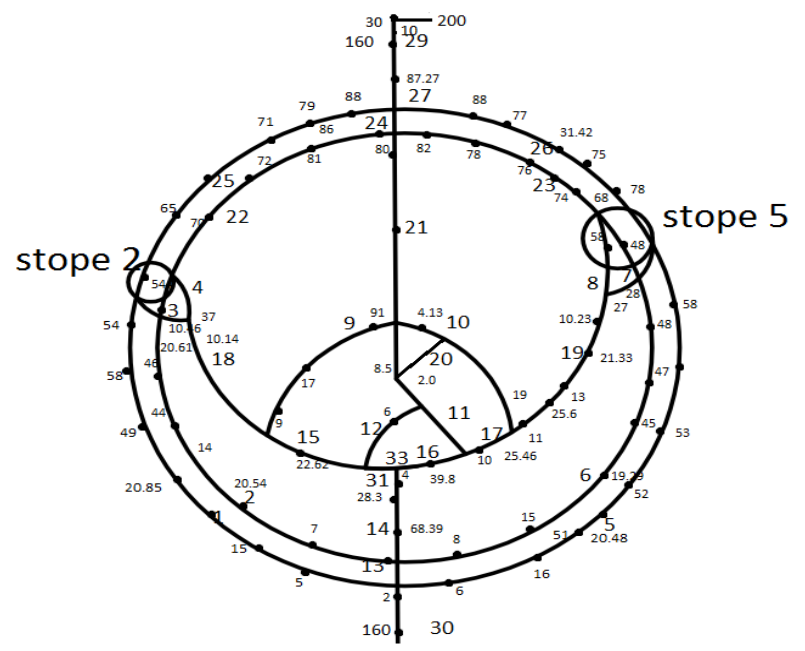

Figure 4: Maddahapara ventilation network data analysis diagram 


\section{METHODOLOGY}

The quantity of air passing through any airway every second, Q is generally given by the expression $[4,9,10,11]$

Where,

$$
Q=\mathbf{U} \times \mathbf{A}\left(\mathbf{m}^{3} / \mathbf{s}\right)
$$

$\mathrm{U}=$ Velocity of air passing through that point $(\mathrm{m} / \mathrm{s})$

$\mathrm{A}=$ Area of roadway $\left(\mathrm{m}^{2}\right)$

Thus, to calculate the quantity of air flowing past any measuring station, it is necessary

a) To ascertain the cross-sectional area of the passage $=\mathrm{A} \mathrm{m}^{2}$.

b) To measure the velocity of air current $=\mathrm{V}(\mathrm{m} / \mathrm{s})$

The air flow measuring point showing at figure 4 .

\section{RESULT AND DISCUSSION}

Maddahapara ventilation fan capacity $200 \mathrm{~m}^{3 / \mathrm{s}}$. But we have found $160 \mathrm{~m}^{3} / \mathrm{s}$ air flows in the ventilation survey. Based on analysis result, the air loss amount $20 \%$ which is the large amount are shown in table 1 and table 2 . In the internationally air flow loss 5\% allow in ventilation system.

\section{A. Causes of Air Flow Loss}

The causes of air flow losses are described below

\section{A.1 Auto Compression}

Auto compression is the increase in air temperature with depth resulting from the weight of the column compressing the air. This is generally expected as $10^{\circ} \mathrm{C}$ (dry bulb) per $1000 \mathrm{~m}$. Based on this air delivered to the $220 \mathrm{~m}$ level will increase by $3.0^{\circ} \mathrm{C}$.

\section{A. 2 Explosives}

Only 5\% of the energy produce by blasting is used to break the rock, the remaining $95 \%$ is released as heat. For many years it was thought that this heat was dissipated directly to the ventilation system and removed during the re-entry period. It is now more widely accepted that this heat is transferred to the broken rock and liberated over a much longer period which is variable and dependent upon ventilation and rock surface exposure.

There has not been any attempt to quantify this head load. The importance of this rate is to raise awareness for design of ventilation circuits to ensure,

- Stop draw points up cast, taking heat away from loading operations.

- That airflow to the charging level is directed first over personnel working on the level and then over the rock pile directly to exhaust.

\section{A. 3 Machinery}

All machinery has inefficiencies converting input energy into mechanical output, this results in heat loss to the environment. The general principle applied is that all electrical energy consumed is converted to either heat energy, or useful work, which is only achieved by raising the potential energy of an object to a higher elevation against the force of gravity. For example, fans do not do any useful work and all energy into output into the motor is converted to heat energy. There has not been any attempt to calculate the heat load at Maddahapara and is outside the scope of this review. The importance of this note is to raise awareness of potential heat sources that are in the intake air circuit. For example, pump stations and electric locomotives.

\section{A. 4 Workplace Temperatures}

Table 4 -data shows that when workplace temperature $28^{\circ} \mathrm{C}$ then the surface ambient temperature rises above $26^{\circ} \mathrm{C}$ wet bulb Until a more thorough investigation of surface climate data and underground heat loads is completed. It is noted that this procedure has been develop for workers wearing lightweight cotton clothing [11,12]. During the site visit, it was noted that underground employees were wearing plastic waterproof clothing. The need for this type of clothing must be reassessed as it prevents the evaporation of sweat from the body, which is necessary to assist cooling. In the view of proposed work practice, a design ACP of $200 \mathrm{w} / \mathrm{m}^{2}$ is considered optimum with modified working times occurring when the cooling power of the air falls below $140 \mathrm{w} / \mathrm{m}^{2}$. To assist with this determination the cooling power charts (table 3 ), should be used. As the mine extends and the residence time of airflow through the circuit increase, the heat transfer from the rock to the airflow will also increase [11]. As a result of this it could reasonably be expected that wet bulb temperatures would exceed $32^{\circ} \mathrm{C}$ during the hottest period of the year.

\section{B. Proposed Optimized Air Flow}

Based on the inspection result the total mine airflow is determined to be $160 \mathrm{~m}^{3} / \mathrm{s}$. Due to expected high leakage component of an extended mine, these velocities may be difficult to maintain. The result of lower air velocity will be an increase in Workplace temperatures. Based on Maddahapara Granite Mine Physiological parameters, surface meteorological parameters, geological parameters, production and mining parameters there are three possible options -

- Increase mine air flow

- Install an air-cooling plant

- Both Increase mine air flow and Install an air-cooling plant

As the mine shafts will be operating at the maximum recommended velocities, any increase in air- flow will require the development of an additional shaft. Cooling power concepts need to be introduced with caution as the vast majority of studies have been conducted on essentially nude male South Africa miners. Further studies have provided an allowance for clothing that again has its origins in South Africa mines and is dependent upon material type. Again, it is noted the wearing of waterproof clothing shields any benefit that may be provided by air velocity. The optimum economic velocities that are applied for the purpose of ACP are invariably between $0.5 \mathrm{~m} / \mathrm{s}$ and $1.5 \mathrm{~m} / \mathrm{s}$ but mostly between $0.75 \mathrm{~m} / \mathrm{s}$ and $1.0 \mathrm{~m} / \mathrm{s}$. It is noted that the effectiveness of air velocity improving ACP is diminished by the practical difficulties of increasing airflow to workplace.

\section{B.1 Ventilation Doors and Controls}

To provide the proposed ventilation circuits will require the installation and maintenance of many doors, regulators and seals. The ultimate effectiveness of these controls will dictate the ambient conditions in the production and development areas. 
Table 1: Data analysis of ventilation in Production level of Maddahapara granite mine

\begin{tabular}{|c|c|c|c|c|c|c|}
\hline Level & Position of inspection & $\begin{array}{c}\text { Design amount } \\
\left(\mathrm{m}^{3} / \mathbf{s}\right)\end{array}$ & $\begin{array}{c}\text { Cross-section } \\
\left(\mathbf{m}^{3}\right)\end{array}$ & $\begin{array}{c}\text { Velocity } \\
(\mathbf{m} / \mathbf{s})\end{array}$ & $\underset{\left(\mathbf{m}^{3} / \mathbf{s}\right)}{\text { Air Amount }}$ & $\begin{array}{c}\text { Air amount } \\
\text { error } \\
\left( \pm \mathbf{m}^{3} / \mathbf{s}\right)\end{array}$ \\
\hline \multirow{28}{*}{ 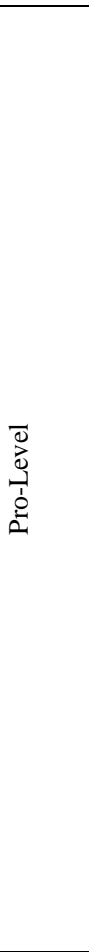 } & North inlet in cage & 59.4 & 12.23 & 4.91 & 60.04 & +0.64 \\
\hline & South inlet in cage & 42.6 & 13.17 & 3.75 & 49.38 & +6.78 \\
\hline & Intake amount in cage shaft & 102 & & & & \\
\hline & Drift into mine car repairing shop & 14.4 & 6.5 & 2.61 & 16.97 & +2.57 \\
\hline & Main Pump & 6 & 3.63 & 1.80 & 6.54 & +0.54 \\
\hline & Roadway in N-E loop & 24.4 & 6.46 & 4.65 & 30.03 & +5.63 \\
\hline & Roadway in N-W loop & 16.6 & 6.46 & 3.58 & 23.13 & +6.54 \\
\hline & Roadway in S-W loop & 17.6 & 7.6 & 3.20 & 24.32 & +6.72 \\
\hline & Roadway in S-E loop & 19 & 7.43 & 3.85 & 28.61 & +9.61 \\
\hline & Roadway air -door-2 in N2 & 20.4 & 4.715 & 4.25 & 20.04 & -0.36 \\
\hline & Roadway air -door-1 in S2 & 17 & 4.715 & 4.65 & 21.93 & +4.93 \\
\hline & Air-door- 27 on boulder crusher in unloading chamber & 6 & 0.62 & 12.70 & 7.88 & +1.88 \\
\hline & $\mathrm{N}$ shunt in roadway to unloading chamber & 4 & 6.67 & 2.58 & 17.20 & +13.20 \\
\hline & Stope-1(N.E) & 8.17 & 6.5 & 1.50 & 9.75 & +1.58 \\
\hline & Stope-1(N.W) & 6.68 & 7.6 & 0.75 & 5.7 & -0.98 \\
\hline & Stope-1(Drill drift) & & 7.27 & 0.63 & 4.58 & +4.58 \\
\hline & Stope-2(N.E) & 6.27 & 6.5 & 1.00 & 6.5 & +0.23 \\
\hline & Stope-2(N.W) & 5.23 & 7.5 & 0.72 & 5.4 & +0.17 \\
\hline & Stope-2(Drill drift) & & 7.3 & 0.65 & 4.75 & +4.75 \\
\hline & Stope-3(N.E) & 5.85 & 6.5 & 1.27 & 8.26 & +2.40 \\
\hline & Stope-3(N.W) & 4.79 & 7.6 & 0.80 & 6.08 & +1.30 \\
\hline & Stope-3(Drill drift) & & 6.9 & 0.36 & 2.50 & +2.50 \\
\hline & Stope-4(S, E) & 8.86 & 7.2 & 2.20 & 15.85 & +6.98 \\
\hline & Stope-4(S, W) & 9.42 & 7.42 & 1.52 & 11.28 & +1.86 \\
\hline & Stope-4(Drill drift) & & 7.24 & 1.20 & 8.69 & +8.69 \\
\hline & Stope-5(S, E) & 8.03 & 6.77 & 1.55 & 10.50 & +2.47 \\
\hline & Stope-5(S, W) & 8.18 & 7.5 & 1.3 & 9.75 & +1.57 \\
\hline & Stope-5(Drill drift) & & 7.3 & 0.8 & 5.84 & +5.84 \\
\hline $\begin{array}{l}\text { Skip - } \\
\text { Tower }\end{array}$ & $+31.2 \mathrm{~m}$ Level & 30.0 & 8.7 & $\begin{array}{c}\text { Average } \\
7.30\end{array}$ & 63.51 & +33.51 \\
\hline
\end{tabular}

Table 2: Data analysis of Ventilation In -vent and Sub-Level of Maddahapara granite mine

\begin{tabular}{|c|c|c|c|c|c|c|}
\hline Level & Position of inspection & $\begin{array}{c}\text { Design amount } \\
\left(\mathrm{m}^{3} / \mathrm{s}\right)\end{array}$ & $\begin{array}{c}\text { Cross section } \\
\left(\mathbf{m}^{2}\right)\end{array}$ & $\begin{array}{c}\text { Velocity } \\
(\mathbf{m} / \mathbf{s})\end{array}$ & $\begin{array}{c}\text { Air Amount } \\
\left(\mathbf{m}^{3} / \mathbf{s}\right)\end{array}$ & $\begin{array}{c}\text { Air amount error } \\
\left( \pm \mathrm{m}^{3} / \mathrm{s}\right)\end{array}$ \\
\hline \multirow{12}{*}{ 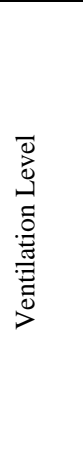 } & North inlet in cage & 14.4 & 10.56 & 1.62 & 17.11 & +2.71 \\
\hline & South inlet in cage & 9.6 & 10.56 & 1.50 & 15.84 & +6.24 \\
\hline & Outlet amount in N-E loop & 35.26 & 7.53 & 6.25 & 47.06 & +11.8 \\
\hline & Outlet amount in S-E loop & 27.63 & 7.55 & 5.30 & 40.02 & +12.39 \\
\hline & Total outlet amount in Vent-level & 62.89 & & & 120.03 & +57.14 \\
\hline & Wing-door-31 in S-W roadway & 9.6 & 1.84 & 10.10 & 18.58 & +8.98 \\
\hline & Wing-door-32 in N-W roadway & 14.4 & 2.03 & 8.10 & 16.44 & +2.04 \\
\hline & Stope-1 & 5.57 & 8 & 1.10 & 8.8 & +3.23 \\
\hline & Stope-2 & 4.57 & 7.56 & 0.91 & 6.88 & +2.31 \\
\hline & Stope-3 & 4.35 & 7.94 & 1.70 & 13.5 & +9.15 \\
\hline & Stope-4 & 4.95 & 6.45 & 1.50 & 9.68 & +4.73 \\
\hline & Stope-5 & 4.62 & 7.45 & 1.70 & 12.67 & +8.05 \\
\hline \multirow{12}{*}{ 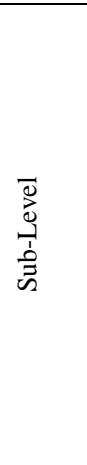 } & North inlet in cage & 14.4 & 10.41 & 1.40 & 14.57 & +0.17 \\
\hline & South inlet in cage & 9.6 & 10.58 & 1.40 & 14.81 & +5.21 \\
\hline & Outlet amount in N-E loop & 34.27 & 7.2 & 5.50 & 39.6 & +5.33 \\
\hline & Outlet amount in S-E loop & 26.43 & 7.1 & 4.10 & 29.11 & +2.68 \\
\hline & Total outlet amount in Vent-level & 60.7 & 10.4 & & 98.09 & +37.39 \\
\hline & Wing-door-29 in S-W roadway & 9.6 & 1.65 & 10.30 & 17 & +7.40 \\
\hline & Wing-door-30 in S-W roadway & 14.4 & 2.03 & 7.70 & 14.21 & -0.19 \\
\hline & Stope-1 & 5.49 & 8.50 & 1.08 & 9.18 & +3.69 \\
\hline & Stope-2 & 4.55 & 8.42 & 1.10 & 9.26 & +4.71 \\
\hline & Stope-3 & 4.33 & 8.56 & 1.35 & 11.57 & +7.24 \\
\hline & Stope-4 & 4.99 & 8.58 & 2.10 & 18.02 & +13.03 \\
\hline & Stope-5 & 4.67 & 9.7 & 1.45 & 14.07 & +9.40 \\
\hline
\end{tabular}


Table 3: Estimation on mean Summer temperature of Maddhapara Granite-Mine

\begin{tabular}{|c|c|c|c|c|c|c|c|c|c|c|c|c|c|}
\hline & & & & & \multicolumn{3}{|c|}{ CASE-1 } & \multicolumn{3}{|c|}{ CASE-2 } & \multicolumn{3}{|c|}{ CASE-3 } \\
\hline Location & $\begin{array}{c}\text { RL } \\
\text { Relative } \\
\text { to sea } \\
\text { level }(\mathrm{m}) \\
\end{array}$ & $\begin{array}{c}\text { Barometric } \\
\text { Pressure } \\
\text { Kpa }\end{array}$ & $\begin{array}{l}\text { VRT } \\
\left({ }^{\circ} \mathrm{C}\right)\end{array}$ & $\begin{array}{c}\text { Airflow } \\
\left(\mathrm{m}^{3} / \mathrm{s}\right)\end{array}$ & $\begin{array}{l}\text { TwB } \\
\left({ }^{\circ} \mathrm{C}\right)\end{array}$ & $\begin{array}{l}\mathrm{T}_{\mathrm{DB}} \\
\left({ }^{\circ} \mathrm{C}\right)\end{array}$ & $\begin{array}{c}\text { ACP } \\
\left(\mathrm{w} / \mathrm{m}^{2}\right)\end{array}$ & $\begin{array}{l}\text { TwB } \\
\left({ }^{\circ} \mathrm{C}\right)\end{array}$ & $\begin{array}{l}\mathrm{T}_{\mathrm{DB}} \\
\left({ }^{\circ} \mathrm{C}\right)\end{array}$ & $\begin{array}{c}\text { ACP } \\
\left(w / m^{2}\right)\end{array}$ & $\begin{array}{l}\text { TwB } \\
\left({ }^{\circ} \mathrm{C}\right)\end{array}$ & $\begin{array}{l}\mathrm{T}_{\mathrm{DB}} \\
\left({ }^{\circ} \mathrm{C}\right)\end{array}$ & $\begin{array}{c}\text { ACP } \\
\left(\mathrm{w} / \mathrm{m}^{2}\right)\end{array}$ \\
\hline Sea level & 0 & 101.325 & & & & & & & & & & & \\
\hline Surface & 32 & 100.948 & 27.2 & 160 & 26.0 & 32.0 & - & 27.0 & 33.0 & - & 29.0 & 35.0 & - \\
\hline Case-Shaft & -228 & 104.008 & 32.9 & 115 & 27.0 & 32.7 & 280 & 28.0 & 33.8 & 264 & 30.0 & 35.7 & 235 \\
\hline Case-Shaft & -270 & 104.502 & 33.4 & 70 & 27.1 & 32.8 & 283 & 28.1 & 33.8 & 256 & 30.1 & 35.7 & 227 \\
\hline Case-Shaft & -270 & 104.502 & 34.0 & - & 27.2 & 32.9 & 256 & 28.2 & 33.9 & 243 & 30.2 & 35.8 & 216 \\
\hline $\begin{array}{c}\text { Drill \& } \\
\text { Blast } \\
\end{array}$ & -228 & 104.008 & 32.9 & 14.0 & 28.7 & 33.0 & 220 & 29.6 & 33.7 & 211 & 31.2 & 34.8 & 191 \\
\hline $\begin{array}{c}\text { Drill \& } \\
\text { Blast }\end{array}$ & -246 & 104.220 & 33.4 & 14.0 & 28.9 & 33.2 & 218 & 29.7 & 33.8 & 209 & 31.4 & 35.1 & 189 \\
\hline Production & -270 & 104.502 & 34.0 & 10.0 & 29.6 & 34.6 & 200 & 30.4 & 35.2 & 191 & 31.9 & 36.2 & 166 \\
\hline & -270 & 104.502 & 34.0 & 20.0 & 28.5 & 32.4 & 231 & 29.4 & 33.1 & 222 & 31.2 & 34.7 & 199 \\
\hline
\end{tabular}

Table 4: Dry bulb temperature of Maddhapara Granite-Mine

\begin{tabular}{|c|c|c|c|c|c|c|c|c|c|c|c|c|c|}
\hline & \multicolumn{13}{|c|}{ WET BULB $^{\circ} \mathrm{C}$} \\
\hline \multirow{19}{*}{ 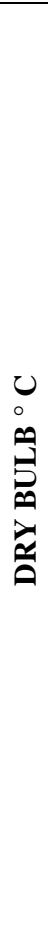 } & & 24 & 25 & 26 & 27 & 28 & 29 & 30 & 31 & 32 & 33 & 34 & 35 \\
\hline & 40 & 168 & 163 & 158 & 154 & 149 & 144 & 139 & 131 & 120 & 108 & 95 & 81 \\
\hline & 39 & 172 & 167 & 162 & 157 & 153 & 148 & 142 & 133 & 122 & 110 & 97 & 83 \\
\hline & 38 & 175 & 170 & 166 & 161 & 156 & 152 & 145 & 136 & 124 & 112 & 99 & 85 \\
\hline & 37 & 179 & 174 & 169 & 165 & 160 & 156 & 148 & 138 & 127 & 114 & 101 & 87 \\
\hline & 36 & 183 & 178 & 173 & 169 & 164 & 159 & 150 & 140 & 128 & 116 & 102 & 88 \\
\hline & 35 & 185 & 182 & 177 & 173 & 168 & 162 & 153 & 143 & 130 & 117 & 104 & 90 \\
\hline & 34 & 188 & 185 & 181 & 177 & 172 & 165 & 156 & 145 & 132 & 120 & 106 & \\
\hline & 33 & 191 & 188 & 184 & 181 & 176 & 168 & 158 & 147 & 134 & 121 & & \\
\hline & 32 & 194 & 191 & 187 & 184 & 179 & 170 & 160 & 149 & 136 & & & \\
\hline & 31 & 197 & 194 & 190 & 187 & 182 & 173 & 162 & 150 & & & & \\
\hline & 30 & 200 & 197 & 193 & 190 & 184 & 175 & 164 & & & & & \\
\hline & 29 & 203 & 200 & 196 & 192 & 186 & 178 & & & & & & \\
\hline & 28 & 206 & 203 & 199 & 193 & 187 & & & ptimı & & & & \\
\hline & 27 & 209 & 205 & 201 & 195 & & & & Cautic & & & & \\
\hline & 26 & 212 & 208 & 203 & & & & & Todifi & & & & \\
\hline & 25 & 215 & 210 & & & & & & Stop & & & & \\
\hline & 24 & 218 & & & & & & & & & & & \\
\hline & & 24 & 25 & 26 & 27 & 28 & 29 & 30 & 31 & 32 & 33 & 34 & 35 \\
\hline
\end{tabular}


Consideration should be given to the following point:

- Airlock doors must be designed to restrict airflow to between $2 \mathrm{~m}^{3} / \mathrm{s}$ and $4 \mathrm{~m}^{3} / \mathrm{s}$ with only one door closed.

- Doors will be required at both ends of the loading drives of each stope on the $270 \mathrm{~m}$ level. These doors should allow for the control of airflow through these drives the anticipated range of flow would be form $0.0 \mathrm{~m}^{3} / \mathrm{s}$ to $10.0 \mathrm{~m}^{3} / \mathrm{s}$.

- Controls for airflow to stopes should be located on the intake (fresh air), side of the stope. This would enable the setting of these controls after blasting without the necessity to enter the blasting gases.

- All stope draw-points should be sealed once loading is complete.

\section{B.2 Maintenance of Ventilation Equipment}

- Operation of main fan should be definitely conduct as per operation manual and the status of maintenance should be recorded operation dairy should be logged regularly and left with the signatures of handover and takeover.

- It is principle to conduct maintenance on rest day and may be one of the two fans can be operated as per decision of personal in charge in mine.

- Ventilation department of mine should always control the condition of installation, operation and maintenance of local fan installed in the underground and $\log$ in details on the equipment logbook regarding their maintenance.

- As the air intake is conducted through case shaft, the case, in need of stoppage, should be parked in production level to avoid any hindrance to intake.

- Main Fan should be stopped only as per instruction of personal in charge of mine and record the relevant reason, stop time and the time lapsed in the logbook.

\section{CONCLUSION}

The mine ventilation streamlining, wind current control are the mine ventilation framework's two critical angles, great ventilation enhancement configuration can convey natural air to build up sustainable workplace and give a logical and dependable premise to forecast danger. The bound for the airflow quantity and the regulated quantity and so on as constraint condition, can be satisfied the ventilation demand and the working condition, causes the expense which the mine ventilation needs to be least, thus is suitable in solving each kind of mine ventilation network optimization adjustment question. Maddhapara mine ventilation optimize, if should be installed cooling plant or increasing air flow in the mine. Thus, install ventilation doors, regulator doors, seal doors and maintenance the ventilation equipment also optimize and controlling the Maddhapara ventilation system.

\section{REFERENCES}

[1] Rahman, A., 1987. Geology of Maddahapara area, Dinajpur district, Bangladesh. Recent Geological Survey of Bangladesh, v. 5, n. 2, pp. 161.

[2] Mohammad Tofayal Ahmed, H. M. Zakir Hossain, Environmental Impact Assessment of Madhyapara Granite Mine,Northwest Bangladesh.

[3] M.A. Akbar, "An Assessment of the geothermal potential of Bangladesh", United Nations University -Geothermal Training PrograMme, Report no. 5. pp. 1-33, 2011

[4] V. Tauli-Corpuz, "The globalisation of mining and its impact and challenges for women", 1997.

[5] Wallace, K.G et al (1986) Impact of using auxiliary fans on mine ventilation efficiency and cost. AIME meeting. New Orleans, March 1986.

[6] M.M. Makweba, and P.B. Ndonde "The mineral sector and the national environmental policy", Proceedings of the workshop on the national environmental policy for Tanzania (Dar es Salaam, Tanzania), pp. 164e 73, 1996

[7] R. Moody, S.P. Panos, "Report Environmental assessment of mining projects", 1997.

[8] T.M. Akabzaa, "The environmental and social impacts of mining in the Wassa West District of Ghana", Accra, Third World Network e Africa, 2000

[9] McElroy, G.W. (1954). A Network Analyzer for Solving Mine Ventilation Distribution Problems. U.S. Bureau of Mines Inf. Circ. 7704. $13 \mathrm{pp}$.

[10] Cross, H. (1936). Analysis of Flow in Networks of conduits or Conductors. Bull. Illinois University Eng. Exp. Station. No. 286

[11] Scott, D.R., Hinsley, F.B., and Hudson, R.F. (1953). A Calculator for the Solution of Ventilation Network Problems. Trans. Inst. Mine. Eng. Vol. 112. p. 623

[12] McPherson, M.J. (1984). Mine Ventilation Planning in the 1980's. International Journal of Mining Engineering. Vol. 2. pp. 185-227. 